mł. bryg. dr inż. Tomasz Drzymałaa)*, dr inż. Bartosz Zegardłob), dr inż. Wioletta Jackiewicz-Rek ${ }^{c}$, inż. Daniel Sowiński

\author{
a) Szkoła Główna Służby Pożarniczej, Wydział Inżynierii Bezpieczeństwa Pożarowego / The Main School of Fire Service, Faculty of Fire \\ Safety Engineering \\ b) Uniwersytet Przyrodniczo-Humanistyczny w Siedlcach, Wydział Przyrodniczy / Siedlce University of Natural Sciences and \\ Humanities, Faculty of Natural Sciences \\ c) Politechnika Warszawska, Wydział Inżynierii Lądowej / Warsaw University of Technology, Faculty of Civil Engineering \\ *Autor korespondencyjny / Corresponding author: t.drzymala@sgsp.edu.pl
}

\title{
Wpływ wysokiej temperatury na zmianę wytrzymałości na zginanie zapraw cementowych modyfikowanych dodatkiem wtókien polipropylenowych
}

\author{
The Effect of High Temperatures on the Flexural Strength of Cement Mortar Modified \\ by the Addition of Polypropylene Fibres
}

\section{Влияние высокой температуры на изменение прочности при изгибе цементных растворов, модифицированных добавлением полипропиленовых волокон}

\footnotetext{
ABSTRAKT

Cel: Celem artykułu jest określenie wpływu oddziaływania wysokiej temperatury na zmianę wytrzymałości na zginanie zaprawy cementowej z dodatkiem oraz bez dodatku włókien polipropylenowych (PP) zgodnie z założoną procedurą badawczą. Ze względu na niejednorodny charakter oraz wrażliwość na wzrost temperatury kruszywa grubego zawartego w betonie, materiał ten w badaniach zastąpiono zaprawą cementową z dodatkiem oraz bez dodatku włókien polipropylenowych.

Wprowadzenie: Przeprowadzone badania miały na celu ocenę, jak dodatek włókien polipropylenowych wpływa na zmianę wytrzymałości analizowanych materiałów na zginanie. Ta cecha wytrzymałościowa w dużym stopniu wpływa na zjawisko termicznego eksplozyjnego odpryskiwania betonu (ang. thermal spalling). W ramach pracy wykonano serię badań polegających na pomiarze wytrzymałości na zginanie uprzednio wygrzanych próbek w zakresie temperatur od 20 do $600^{\circ} \mathrm{C}$ z dodatkiem oraz bez dodatku włókien polipropylenowych (PP). Do badań zastosowano jeden typ włókna dla wszystkich wariantów badań wytrzymałościowych, zgodnie z założonym planem eksperymentu.

Metody: Artykuł opracowano w oparciu o pomiary spadków wytrzymałości na zginanie dla prostopadłościennych beleczek o wymiarach $40 \times 40 \times 160$ mm Porównano wyniki badań dla kompozytów cementowych z dodatkiem oraz bez dodatku włókien, wygrzewanych w podwyższonych temperaturach Zestawienie otrzymanych wyników przedstawiono na wykresach.

Wyniki: Porównanie wyników badania próbek z dodatkiem oraz bez dodatku włókien prowadzi do wniosku, że dodatek włókien wpływa na poprawę wytrzymałości na zginanie kompozytów cementowych w podwyższonych temperaturach.

Wnioski: W całym zakresie temperatur od 20 do $600^{\circ} \mathrm{C}$ zaprawy cementowe z dodatkiem włókien polipropylenowych wykazały się wyższą wytrzymałością na zginanie. Wygrzewanie badanych zapraw bez dodatku oraz z dodatkiem włókien polipropylenowych spowodowało wyraźny spadek ich wytrzymałości na zginanie wraz ze wzrostem temperatury. Dodatek włókien polipropylenowych (PP) w ilości 1,8 kg/m³ może znacząco ograniczać powstawanie rys i pęknięć w pierwszej fazie dojrzewania betonu. Wykonane badania potwierdzają zasadność stosowania włókien polipropylenowych do zaprawy cementowej, ponieważ dodatek ten miał wpływ na poprawę wytrzymałości badanego kompozytu cementowego na zginanie zarówno w wysokich temperaturach, jak i w temperaturze normalnej (pokojowej). Pozytywny wpływ włókien polipropylenowych potwierdzają również badania przeprowadzone w kraju i za granicą.

Słowa kluczowe: kompozyt cementowy, włókna polipropylenowe, wytrzymałość, termiczne odpryskiwanie, wytrzymałość na zginanie, wysoka temperatura, beton

Typ artykułu: oryginalny artykuł naukowy

Przyjęty: 12.03.2018; Zrecenzowany: 03.09.2018; Zatwierdzony: 05.11.2018;

Procentowy wkład merytoryczny: T. Drzymała - 85\%; B. Zegardło - 5\%; W. Jackiewicz-Rek - 5\%; D. Sowiński - 5\%;

Identyfikatory ORCID autorów: T. Drzymała - 0000-0001-9568-3235; B. Zegardło - 0000-0002-1292-3107; W. Jackiewicz-Rek - 0000-0001-6056-5458;

Proszę cytować: BiTP Vol. 51 Issue 3, 2018, pp. 26-39, doi: 10.12845/bitp.51.3.2018.2;

Artykuł udostępniany na licencji CC BY-SA 4.0 (https://creativecommons.org/licenses/by-sa/4.0/)
} 


\section{ABSTRACT}

Aim: The aim of this paper is to determine the effect of high temperature on changes in the flexural strength of cement mortar with and without the addition of polypropylene fibres (PP), following a predefined test procedure. In order to eliminate the effect of coarse aggregate on the flexural strength of the composite, cement mortar with the addition of polypropylene fibres was used in the tests. Due to the fact that coarse aggregate is inhomogeneous and sensitive to temperature increases, it could significantly distort the results.

Introduction: The aim of the study was to show how the addition of polypropylene fibres influenced changes in the flexural strength. Due to the fact that this strength has a significant impact on the phenomenon of thermal spalling, it was the main focus of the study. As part of the study, a range of tests were performed to measure the flexural strength of samples with and without the addition of polypropylene fibres, pre-heated at temperatures ranging from $20^{\circ} \mathrm{C}$ to $600^{\circ}$. One type of fibre was used for all the variants of strength tests, in line with the plan of the experiment.

Methods: The paper is based on measurements of the flexural strength reductions for rectangular-prism bars sized $40 \times 40 \times 160 \mathrm{~mm}$. The test results for composites with and without the addition of fibres heated at different temperatures were compared and presented in detailed diagrams.

Results: A comparison of the results of tests involving samples with and without the addition of PP fibres leads to the conclusion that the addition of PP fibres significantly improves the flexural strength of cementitious composites.

Conclusions: In the entire temperature range from $20^{\circ} \mathrm{C}$ to $600^{\circ} \mathrm{C}$, cement mortars with polypropylene fibres showed higher flexural strengths. The heating of mortars with and without the addition of polypropylene fibres resulted in a significant decrease in their tensile strengths as the temperature increased. The addition of $1.8 \mathrm{~kg} / \mathrm{m}^{3}$ in polypropylene fibres can significantly reduce the cracking in the first phase of concrete hardening. The tests confirmed the applicability of polypropylene fibres in cement mortar, as their addition significantly improves the flexural strength at both high and normal temperatures. The positive effect of polypropylene fibres is also confirmed by other studies conducted in Poland and abroad.

Keywords: cement composite, polypropylene fibres, strength, thermal spalling, flexural strength, high temperature, concrete

Type of article: original scientific article

Received: 12.03.2018; Reviewed: 03.09.2018; Accepted: 05.11.2018;

Percentage contribution: T. Drzymała - 85\%; B. Zegardło - 5\%; W. Jackiewicz-Rek - 5\%; D. Sowiński - 5\%;

Authors' ORCID IDs: T. Drzymała - 0000-0001-9568-3235; B. Zegardło - 0000-0002-1292-3107; W. Jackiewicz-Rek - 0000-0001-6056-5458;

Please cite as: BiTP Vol. 51 Issue 3, 2018, pp. 26-39, doi: 10.12845/bitp.51.3.2018.2;

This is an open access article under the CC BY-SA 4.0 license (https://creativecommons.org/licenses/by-sa/4.0/).

\section{АННОТАЦИЯ}

Цель: Цель статьи - определить влияние воздействия высокой температуры на изменение прочности при изгибе цементного раствора с добавлением и без добавления полипропиленовых волокон (ПП) в соответствии с предполагаемой исследовательской процедурой. Из-за неоднородного характера и чувствительности к увеличению температуры крупного заполнителя, содержащегося в бетоне, этот материал в испытаниях был заменен цементным раствором с добавлением и без добавления полипропиленовых волокон.

Введение: Проведенные исследования были направлены на оценку того, как добавление полипропиленовых волокон влияет на изменение прочности анализируемых материалов при изгибе. Эта особенность прочности сильно влияет на явление термического отслаивания (ang. thermal spalling). В рамках этой работы была проведена серия испытаний, состоящая из измерения прочности при изгибе предварительно нагретых образцов в температурном диапазоне от 20 до $600^{\circ} \mathrm{C}$ с добавлением и без добавления полипропиленовых волокон (ПП). В соответствии с предполагаемым планом эксперимента использовался один тип волокна для всех вариантов испытаний на прочность.

Методы: Статья была разработана на основе измерений снижений прочности при изгибе для прямоугольных балок 40 × 40 × 160 мм. Сравнивались результаты испытаний цементных композитов с добавлением и без добавления волокон, нагретых при повышенных температурах. Краткое изложение полученных результатов показано на диаграммах.

Результаты: Сравнение результатов испытаний образцов с добавлением волокон и без них привело к выводу, что добавление волокон улучшает прочность при изгибе цементных композитов в условиях высоких температур.

Выводы: во всем диапазоне температур от 20 до $600^{\circ} \mathrm{C}$ цементные растворы с добавлением полипропиленовых волокон демонстрируют более высокую прочность на изгиб. Нагревание тестируемых растворов без добавления и с добавлением полипропиленовых волокон привело к значительному снижению их прочности при изгибе в условиях повышенных температур. Добавление полипропиленовых волокон (ПП) в количестве 1,8 кг/м³ может значительно уменьшить появление линий и трещин в первой фазе созревания бетона. Проведенные испытания подтверждают целесообразность использования полипропиленовых волокон для цементного раствора, поскольку эта добавка влияет на повышение прочности испытываемого цементного композита при изгибе как при высоких температурах, так и при нормальной (комнатной) температуре. Положительное влияние полипропиленовых волокон также подтверждается исследованиями, проводимыми в стране и за рубежом.

Ключевые слова: цементный композит, полипропиленовые волокна, прочность, термическое отслаивание, прочность на изгиб, высокая температура, бетон

Тип статьи: оригинальная научная статья

Принята: 12.03.2018; Рецензирована: 03.09.2018; Одобрена: 05.11.2018;

Процентное соотношение участия в подготовке статьи: T. Drzymała - 85\%; B. Zegardło - 5\%; W. Jackiewicz-Rek - 5\%; D. Sowiński - 5\%;

Идентификаторы ORCID авторов: T. Drzymała - 0000-0001-9568-3235; B. Zegardło - 0000-0002-1292-3107;

W. Jackiewicz-Rek - 0000-0001-6056-5458;

Просим ссылаться на статью следующим образом: BiTP Vol. 51 Issue 3, 2018, pp. 26-39, doi: 10.12845/bitp.51.3.2018.2;

Настоящая статья находится в открытом доступе и распространяется в соответствии с лицензией CC BY-SA 4.0 (https://creativecommons.org/ licenses/by-sa/4.0/). 


\section{Wstęp}

Wysoka temperatura niekorzystnie wpływa na właściwości kompozytów cementowych [1-11]. W warunkach pożarowych konstrukcje betonowe o dużej zawartości wilgoci oraz wykonane $z$ betonu o wysokiej wytrzymałości (HSC, high-strength concrete) mają tendencję do termicznego eksplozyjnego odpryskiwania (ang. thermal spalling). Zjawisko to dotyczy przede wszystkim betonu z niskim wskaźnikiem wodno-cementowym (w/c), wysoką wytrzymałością na ściskanie oraz zwartą matrycą cementową [3, 12]. Odspojenie od konstrukcji dużych fragmentów betonu powoduje odkrycie stali zbrojeniowej, a przez to obniżenie wytrzymałości konstrukcji. W efekcie może prowadzić to do jej uszkodzenia [3, 6]. Zjawisko "spallingu" stwarza również duże zagrożenie dla ratowników prowadzących działania ratownicze [13-15]. Na przykład w tunelach komunikacyjnych oraz w innych nieogrzewanych pomieszczeniach beton zawiera stosunkowo dużo wilgoci. W czasie pożaru na skutek gwałtownego wzrostu temperatury bardzo często ma wtedy miejsce zjawisko „spallingu” [12, 16-19].

Istnieje wiele prac naukowo-badawczych ukierunkowanych m.in. na badanie pozytywnego wpływu dodatku włókien polipropylenowych (PP) na ograniczenie zjawiska spallingu. Termiczne eksplozyjne odpryskiwanie betonu było przedmiotem m.in. badań objętych projektem UPTUN [19], w którym uczestniczyli również naukowcy z Polski. Do najbardziej efektywnych metod ochrony konstrukcji przed działaniem wysokich temperatur oraz termicznym eksplozyjnym odpryskiwaniem zaliczyć można:

- użycie bariery termicznej (izolacje ogniochronne - zabezpieczenia powierzchni płytami lub warstwą betonu natryskowego),

- zastosowanie włókien polipropylenowych do mieszanki betonowej,

- dodanie środka napowietrzającego do mieszanki betonowej,

- stosowanie kruszywa o niskiej rozszerzalności termicznej.

W Europie istnieje już ponad 15 tys. kilometrów tuneli komunikacyjnych - zarówno w rejonach górskich, jak i miejskich. Temperatura występująca $w$ trakcie pożaru w tunelu jest znacznie wyższa w porównaniu z pożarami budynków.

Zjawisko spallingu jest wciąż przedmiotem dyskusji w środowisku naukowym [3, 20]. Ze względu na bardzo duże znaczenie praktyczne, wielu uczonych na świecie podjęło badania teoretyczne i eksperymentalne, mające na celu szersze poznanie i wyjaśnienie jego przyczyn. Na podstawie ich wyników stworzono kilka teorii, nie uzyskano jednak jednego, spójnego wyjaśnienia mechanizmów jego powstawania. Pod uwagę brane są m.in. takie czynniki jak: wysokie ciśnienie gazu powstałe w wyniku odparowywania wilgoci w przypowierzchniowej warstwie konstrukcji oraz naprężenia rozciągające, które mogą przekroczyć wytrzymałość betonu na rozciąganie [3, 17].

W celu ograniczenia odpryskiwania betonu w warunkach pożarowych do mieszanki betonowej dodaje się włókna PP, na ogół w ilości od $1 \mathrm{~kg} / \mathrm{m}^{3}$ do $2 \mathrm{~kg} / \mathrm{m}^{3}$. llość ta odpowiada $0,4-0,8 \%$ objętości zaczynu cementowego, przy założeniu, że zaczyn cementowy zajmuje $30 \%$ objętości betonu. W celu uzyskania dobrego

\section{Introduction}

High temperatures have an adverse effect on the properties of cement composites [1-11]. In fire conditions, concrete structures with high contents of moisture and made of high-strength concrete show a tendency for thermal spalling. This is primarily the case with low water-cement ratio (w/c) concrete exhibiting a high compressive strength and a dense cement matrix $[3,12]$. The detachment of small concrete fragments from the structure causes the exposure of steel reinforcing bars, thus reducing structural integrity and potentially leading to structural damage $[3,6]$. Furthermore, spalling poses a significant threat to rescuers [13-15]. For example, concrete in road and rail tunnels, and other unheated areas contains relatively large amounts of moisture. In a fire, the sudden increase in temperature frequently causes spalling [12, 16-19].

There is a large body of research on the positive effect of polypropylene (PP) additions on reducing spalling. The spalling of concrete has been studied, among others, as part of the UPTUN project [19], whose participants included Polish scientists. The most effective methods to protect structures against high temperatures and spalling include:

- using thermal barriers (fire insulation - protecting surfaces with panels or shotcrete layers);

- adding polypropylene fibres to the concrete mix;

- adding an aerating agent to the concrete mix;

- using low-thermal-expansion aggregates.

Europe already has more than 15,000 kilometres of road and rail tunnels - in both mountainous and urban areas. During fire, the temperature in a tunnel is much higher than inside a building.

Spalling continues to be a subject of scientific discussion $[3,20]$. Because of its significant practical implications, many scholars around the world have been conducting theoretical and experimental research on spalling to learn more about it and explain its causes. While their findings have led to the formulation of several theories, a consistent explanation of the underlying mechanisms is yet to be proposed. Consideration has been given to such factors as high gas pressure resulting from moisture evaporation in the near-ground layer of the structure and tensile stresses which might exceed the tensile strength of concrete [3, 17].

To reduce spalling in fire conditions, PP fibres are added to the concrete mix, their amounts usually ranging from $1 \mathrm{~kg}$ / $\mathrm{m}^{3}$ to $2 \mathrm{~kg} / \mathrm{m}^{3}$. This constitutes $0.4-0.8 \%$ of the cement slurry volume, assuming that it comprises $30 \%$ of the concrete volume. To achieve good dispersion, fibres are coated with agents that reduce their hydrophobic properties. These may include fatty-acid esters, glycerides, fatty-acid amides or cationic surfactants. The most popular varieties of polypropylene fibres soften and start to melt at a temperature of about $160^{\circ} \mathrm{C}$. In such conditions, the volume of individual fibres shrinks [3]. The spaces left by the fibres form small ducts through which steam is escaping under high pressure. This prevents internal 
rozproszenia w trakcie mieszania włókna są powlekane środkiem zmniejszającym ich właściwości hydrofobowe. Mogą to być środki takie jak estry kwasów tłuszczowych, glicerydy, amidy kwasów tłuszczowych lub kationowe środki powierzchniowo czynne. Najpopularniejsze odmiany włókien polipropylenowych miękną i zaczynają topić się w temperaturze około $160^{\circ} \mathrm{C}$. W takich warunkach dochodzi do zmniejszenia objętości poszczególnych włókien [3]. W przestrzeniach pozostałych po włóknach formują się kanaliki, którymi wydostaje się pod wysokim ciśnieniem para wodna. Dzięki temu naprężenia wewnętrzne nie osiągają punktu krytycznego i nie następuje eksplozyjne odpryskiwanie betonu [21].

Opisany wyżej zabieg technologiczny pozwala przeciwdziałać zjawisku eksplozyjnego odpryskiwania przede wszystkim dzięki obniżeniu maksymalnych wartości ciśnienia pary wodnej poprzez zwiększenie przepuszczalności betonu. Zwiększenie przepuszczalności zachodzi w związku z topnieniem włókien oraz ich pirolizą [1, 22, 23].

W obecnych czasach technologia betonu bardzo się rozwinęła. Świadczy o tym różnorodność używanych składników, dodatków i domieszek. Kompozyt ten ma wiele odmian. Technolodzy mogą go otrzymywać wedle potrzeb [24]. W celu polepszenia właściwości mechanicznych betonu bardzo często oprócz zbrojenia stalowego stosowane są także dodatki w postaci włókien. Najczęściej są to włókna polipropylenowe (PP), stalowe, nylonowe oraz wiele innych tworzyw sztucznych. Beton zbrojony wszelkiego rodzaju włóknami występuje pod wspólną nazwą jako fibrobeton i zaliczany jest do grupy materiałów kompozytowych.

Od wielu lat w Szkole Głównej Służby Pożarniczej prowadzone są badania nad wpływem wysokiej temperatury na zmiany parametrów wytrzymałościowych zarówno betonów zwykłych NSC (normal-strength concrete), jak i betonów wysokowartościowych HSC (high-strength concrete) oraz kompozytów cementowych z dodatkiem włókien polipropylenowych PFRC (polypropylene fibre-reinforced concrete) [25, 26]. Obecnie w SGSP prowadzone są również liczne prace nad optymalizacją dodatku różnego rodzaju włókien polipropylenowych do kompozytów cementowych w celu redukcji występowania zjawiska spallingu [27].

Źródła literaturowe opisujące możliwości wykorzystania włókien polipropylenowych (PP) do kompozytów cementowych poddanych oddziaływaniu wysokich temperatur koncentrują się głównie na redukcji zjawiska rys skurczowych podczas dojrzewania betonu [28], na zjawisku termicznego eksplozyjnego odpryskiwania spallingu oraz ich wpływie na zmianę parametrów wytrzymałościowych [1-27].

W badaniach w celu ograniczenia zmiennego wpływu kruszywa grubego na zmianę wytrzymałości na zginanie jako materiał badawczy zastosowano zaprawę cementową. Przygotowano dwie serie zapraw - z dodatkiem włókien PP oraz bez tego dodatku. Podczas badań analizowano zmianę wytrzymałości zapraw na zginanie, która może odgrywać istotną rolę w termicznym odpryskiwaniu betonu, gdyż oderwanie elementów betonu następuje w momencie przekroczenia jego wytrzymałości na rozciąganie. Zależność ta została wykazana w [27] oraz może mieć duży wpływ na wytrzymałość kompozytu na zginanie. stresses from reaching the critical point, eliminating the risk of explosive concrete spalling [21].

The above-described solution makes it possible to counter explosive concrete spalling primarily because it reduces the maximum values of steam pressure by increasing concrete permeability. This occurs as a result of fibre melting and pyrolysis $[1,22,23]$.

Concrete technology has seen major developments nowadays, as reflected by the diversity of components, additives and admixtures. There are many varieties of this composite. Production engineers can produce it as needed [24]. To improve the mechanical properties of concrete, fibre additives are used apart from steel reinforcing bars. Usually, they are made from polypropylene (PP), steel, nylon and various plastics. Concrete reinforced with any type of fibres is commonly referred to as $\mathrm{fi}^{-}$ bre-reinforced concrete and considered as belonging to a group of composite materials.

For many years now, the Main School of Fire Service (SGSP) has been conducting research into the effect of high temperatures on changes in the strength parameters of both normal-strength concrete and high-strength concrete, as well as polypropylene fibre-reinforced concrete) $[25,26]$. Currently, SGSP is also working extensively on optimising the addition of various types of polypropylene fibres to cement composites to reduce spalling [27].

Literature sources describing possible applications of PP fibres in cement composites exposed to high temperatures focus primarily on the reduction of contraction cracking during concrete hardening [28] and on thermal spalling, and their effect on changes in strength parameters [1-27].

In order to reduce the variable effect of coarse aggregate on changes in the flexural strength the authors used concrete mortar as a study material. Two series of mortars were prepared - with and without the addition of PP fibres. The studies analysed changes in the flexural strength of mortars as having potentially significant implications for the thermal spalling of concrete, since concrete fragments start to break off once the tensile strength of concrete is exceeded. This relationship has been proven [27], and it might have a significant effect on the flexural strength of concrete. 


\section{Program i metodyka badań \\ Cel oraz zakres badań}

Głównym celem badań było określenie wpływu oddziaływania wysokiej temperatury na zmianę wytrzymałości na zginanie zaprawy cementowej z dodatkiem oraz bez dodatku włókien polipropylenowych (PP). Przedstawione w artykule prace badawcze ukierunkowane były również na ocenę możliwości poprawy parametrów wytrzymałościowych kompozytów cementowych poddanych oddziaływaniu wysokich temperatur poprzez wprowadzenie do mieszanki włókien polipropylenowych PP. Próbki do badań wykonano $w$ formie prostopadłościennych beleczek o wymiarach $40 \times 40 \times 160 \mathrm{~mm}$. Próbki po zaformowaniu po 24 godzinach wyjmowano $z$ form i umieszczano $w$ wodzie na 27 dni. W kolejnym etapie badań próbki przeniesiono do komory klimatycznej o $\mathrm{RH}=$ $99 \%$ i temperaturze $20^{\circ} \mathrm{C}$, gdzie przechowywano je przez kolejne 60 dni. Następnie próbki umieszczono w suszarce i w temperaturze $70^{\circ} \mathrm{C}$, suszono je do stałej masy przez $21 \mathrm{dni}$, monitorując przez ten czas ubytek wody. Suszenie badanych próbek zapraw do stałej masy przed procesem wygrzewania wynikało z tego, że próbki wilgotne bez dodatku włókien PP wygrzewane do temperatury $600^{\circ} \mathrm{C}$ ulegały licznym eksplozjom (spalling). Zjawisko to było najbardziej intensywne podczas szybkiego przyrostu temperatury.

Badania przeprowadzono w Szkole Głównej Służby Pożarniczej oraz na Politechnice Warszawskiej. Wytrzymałość na zginanie oznaczano na podstawie procedury opisanej w normie PN-EN 1015-11:2001 [29]. Jako dodatek zastosowano włókna polipropylenowe Fibrofor High Grade 190. Wykonano badania porównawcze dla beleczek bez dodatku włókien oraz z dodatkiem włókien w ilości $1,8 \mathrm{~kg} / \mathrm{m}^{3}$. Temperatury badawcze zawierały się w zakresie od $20^{\circ} \mathrm{C}$ do $600^{\circ} \mathrm{C}$. Próbki wygrzewano w piecu w trzech temperaturach badawczych $\left(200^{\circ} \mathrm{C}, 400^{\circ} \mathrm{C}, 600^{\circ} \mathrm{C}\right)$. W czasie badań dążono do tego, aby rozkład temperatury w czasie był zbliżony do warunków termicznych standardowego pożaru. Po wygrzewaniu w piecu i wystudzeniu, próbki każdorazowo poddawano badaniom oznaczenia wytrzymałości na zginanie.

W każdym punkcie pomiarowym zbadano po 3 próbki (zarówno z dodatkiem oraz bez dodatku włókien PP).

Na rycinie 1 przedstawiono program badań przy oznaczaniu wytrzymałości na zginanie dla beleczek zaprawowych z dodatkiem i bez dodatku włókien polipropylenowych.

\section{Testing regime and methods \\ Aim and scope of study}

The aim of the study was to determine the effect of high temperatures on changes in the flexural strength of cement mortars with and without the addition of polypropylene fibres (PP), following a predefined test procedure. The studies discussed in this article also aimed to examine the possibilities for improving the strength parameters of cement composites exposed to high temperatures by adding PP fibres to the mix. The test samples were made as small, rectangular-prism beams sized $40 \times 40 \times 160 \mathrm{~mm}$. After 24 hours, the formed samples were removed from the mould and placed in water for 27 days. Subsequently, the samples were transferred to a climatic chamber with $\mathrm{RH}=99 \%$ and a temperature of $20^{\circ} \mathrm{C}$, where they were stored for further 60 days. Next, the samples were placed in a dryer and dried to constant weight for 21 days, with water loss being monitored throughout this period. The tested mortar samples were dried to constant weight before heating because moist samples without PP fibres spalled extensively when heated to $600^{\circ} \mathrm{C}$. Spalling was the most extensive when the temperature increased abruptly.

The tests were conducted in the Main School of Fire Service and the Warsaw University of Technology. The flexural strength was determined using the procedure described in the PN-EN 1015-11:2001 standard [29]. Fibrofor High Grade 190 polypropylene fibres were used as the additive. Comparative tests were conducted for beams without fibres and containing $1.8 \mathrm{~kg} / \mathrm{m}^{3}$ of fibres. The test temperatures ranged from $20^{\circ} \mathrm{C}$ to $600^{\circ} \mathrm{C}$. The samples were heated in a furnace at three temperatures $\left(200^{\circ} \mathrm{C}\right.$, $400^{\circ} \mathrm{C}, 600^{\circ} \mathrm{C}$ ). During the tests, measures were taken to make sure that the distribution of temperature in time was similar to the thermal conditions of a regular fire. After each heating and cooling, all of the samples were tested for flexural strength.

Three samples were tested per each measurement point (both with and without PP fibres).

Figure 1 shows the testing regime for the determination of flexural strength for mortar beams with and without the addition of polypropylene fibres.

\section{X) Zmienne wejściowe/Input variables \\ - Temperatura/Temperature $\left(20 ; 200 ; 400 ; 600\left[{ }^{\circ} \mathrm{C}\right]\right)$ \\ B) Zmienne stale/Fixed variables \\ Zaprawa cementowa bez włókien /Mortar without the addition of polypropylene fibres (PP) \\ - Zaprawa cementowa z włóknam (PP) (w ilości 1,8 $\left.\left[\mathrm{kg} / \mathrm{m}^{3}\right]\right) /$ Mortar with the addition of polypropylene fibres (PP) $\left(1.8\left[\mathrm{~kg} / \mathrm{m}^{3}\right]\right)$}

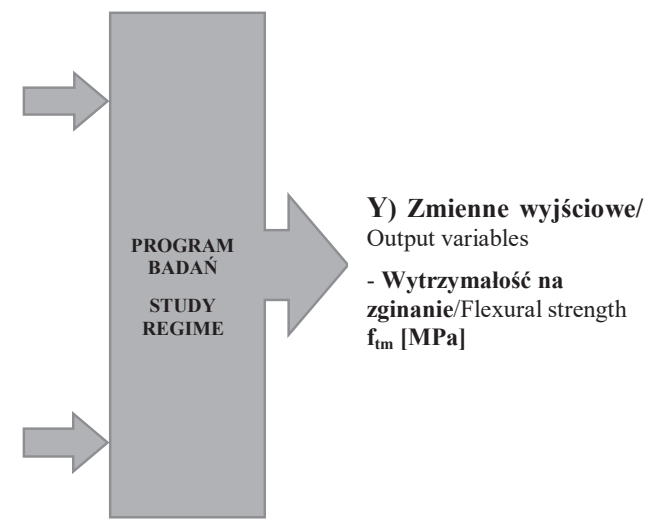

Rycina 1. Program badań przy oznaczaniu wytrzymałości na zginanie $\mathrm{f}_{\mathrm{tm}}$ [MPa]

Figure 1. Testing regime for the determination of flexural strength $f_{t m}[\mathrm{MPa}]$

Źródło: Opracowanie własne.

Source: Own elaboration. 


\section{Charakterystyka użytych materiałów}

Do wykonania zaprawy użyto cement CEM I 42,5 R Lafarge z cementowni Małogoszcz spełniający, wg deklaracji producenta, wymagania normy PN-EN 197-1:2002 [30]. Jako modelowy materiał badawczy przyjęto zaprawę cementową o niskim współczynniku w/c = 0,25, doszczelnioną dodatkiem pyłu krzemionkowego. Do zaprawy wykorzystano piasek wiślany $0 / 2 \mathrm{~mm}$ oraz pył krzemionkowy Silimic. Do zaprawy użyto wodę wodociągową zgodną z wymaganiami PN-EN 1008:2004 [31]. Jako domieszkę użyto Chrysofluid Optima 185 wytwarzaną na bazie modyfikowanych polikarboksylatów i fosfonianów, zgodną z wymaganiami normy PN-EN 934-2 [32]. Zestawienie składów do wykonania próbek zaprawy potrzebnych do realizacji przyjętego planu eksperymentu zamieszczono w tabeli 1.

\section{Characteristics of materials used}

The CEM I 42.5 R Lafarge cement from the Małogoszcz cement plant, compliant with the PN-EN 197-1:2002 standard, as declared by the manufacturer, was used to make the mor$\operatorname{tar}[30]$. Cement mortar with a low $\mathrm{w} / \mathrm{c}$ ratio $=0.25$, additionally sealed with silica liquid, was used as a model test material. Sand from the Vistula River $(0 / 2 \mathrm{~mm})$ and the Silimic silica dust, and network water compliant with the PN-EN 1008:2004 standard [31] were used to make the mortar. The Chrysofluid Optima 185, made from modified polycarboxylates and phosphonates, compliant with the PN-EN 934-2 standard, was used as admixture [32]. A list of sample compositions required to complete the experiment as planned is provided in Table 1.

Tabela 1. Składy zapraw cementowych

Table 1. Compositions of cement mortars

\begin{tabular}{lcc}
\hline \multicolumn{1}{c}{ Składniki/Components } & \multicolumn{2}{c}{ Oznaczenie składu/Composition designation } \\
\cline { 2 - 3 } & 0F & 1.8F \\
\hline Cement/CEM I 42.5 R cement, $\left[\mathrm{kg} / \mathrm{m}^{3}\right]$ & 846 & 846 \\
\hline Mikrokrzemionka/ Microsilica $\left[\mathrm{kg} / \mathrm{m}^{3}\right]$ & 84.6 & 84.6 \\
\hline Piasek/Sand $\left[\mathrm{kg} / \mathrm{m}^{3}\right]$ & 1249 & 1249 \\
\hline Plastyfikator/Optima 185 plasticiser $[\%] \mathrm{m} . \mathrm{c}$. & 2 & 2 \\
\hline Woda/Water $\left[\mathrm{dm}{ }^{3}\right]$ & 215 & 215 \\
\hline Włókna/Fibrofor High Grade 190 fibres $\left[\mathrm{kg} / \mathrm{m}^{3}\right]$ & - & 1.8 \\
\hline
\end{tabular}

Źródło: Opracowanie własne na podstawie [27].

Source: Own elaboration based on [27]

Do badań użyto włókien Fibrofor High Grade typ 190 produkcji firmy Brugg Contec AG. W tabeli 2 podano charakterystykę włókien na podstawie danych producenta [33].
Fibrofor High Grade Type 190 fibres made by Brugg Contec AG were used for the study. Table 2 shows the characteristics of fibres based on manufacturer's data [33].

Tabela 2. Charakterystyka włókien Fibrofor High Grade wykorzystanych do badań

Table 2. Characteristics of Fibrofor High Grade fibres used for the tests

\begin{tabular}{cc}
\hline Właściwość/Property & Nazwa włókien/Fibre name \\
\cline { 2 - 2 } Barwa/Colour & Fibrofor High Grade 190 \\
\hline Charakterystyka/Characteristic & Biązkowane, fibrylowane/Binded, fibrillated \\
\hline Długość/Length $[\mathrm{mm}]$ & 19 \\
\hline Grubość folii/Film thickness $[\mu \mathrm{m}]$ & 80 \\
\hline Gęstość/Density $\left[\mathrm{g} / \mathrm{cm}^{3}\right]$ & 0.90 \\
\hline Wytrzymałość na rozciąganie/Tensile strength $\left[\mathrm{N} / \mathrm{mm}^{2}\right]$ & $\sim 400$ \\
\hline Temperatura mięknienia/Softening temperature $\left[{ }^{\circ} \mathrm{C}\right]$ & approx. 150
\end{tabular}

Źródło: Opracowanie własne.

Source: Own elaboration. badań.

Na rycinie 2 przedstawiono zdjęcie włókien użytych do
Figure 2 shows a picture of the fibres used in the tests. 


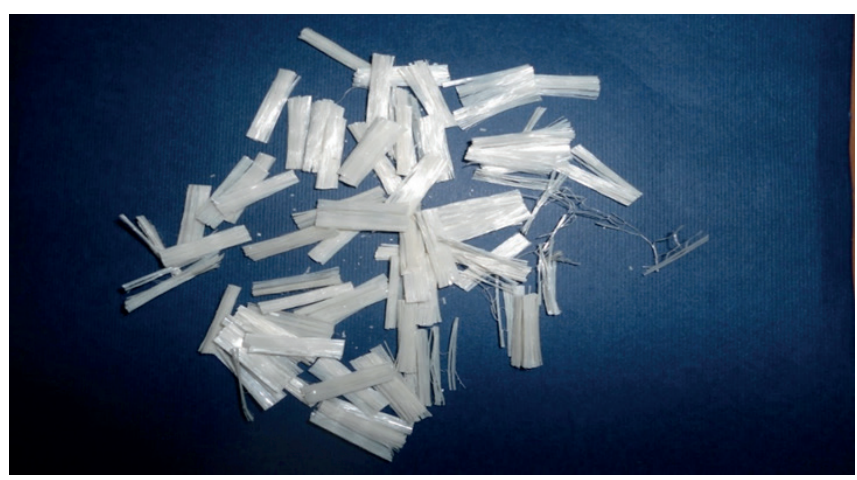

Rycina 2. Włókna polipropylenowe Fibrofor High Grade 190

Figure 2. Fibrofor High Grade 190 polypropylene fibres

Źródło: Opracowanie własne.

Source: Own elaboration.

\section{Opis stanowisk badawczych} Stanowisko do wygrzewania próbek

Wygrzewanie próbek przeprowadzono w Laboratorium Mechaniki i Wytrzymałości Materiałów w Szkole Głównej Służby Pożarniczej. Stanowisko do wygrzewania próbek stanowił elektryczny średniotemperaturowy piec komorowy typu PK 1100/5 wraz z komputerem PC (ryc. 3). Sterownie piecem oraz rejestrowanie temperatury $w$ trakcie wygrzewania próbek odbywało się przy użyciu specjalistycznego oprogramowania.

\section{Description of test stands Sample heating stand}

The samples were heated in the Material Mechanics and Strength Laboratory of the Main School of Fire Service. The heating was done using the PK 1100/5 electric medium-temperature chamber furnace with PC support (Figure 3). Specialised software was employed to control the furnace and record temperatures during sample heating.

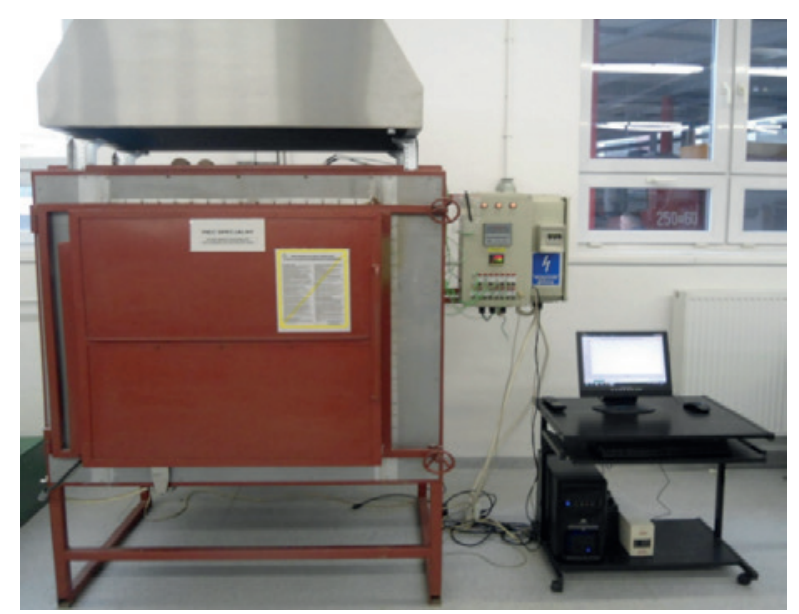

Rycina 3. Stanowisko do wygrzewania próbek

Figure 3. Sample heating stand

Źródło: Opracowanie własne.

Source: Own elaboration.

Po założonym okresie kondycjonowania próbki każdego z kompozytów podzielono na grupy, które poddano procesowi wygrzewania w temperaturach $200^{\circ} \mathrm{C}, 400^{\circ} \mathrm{C} \mathrm{i} 600^{\circ} \mathrm{C}$. Do pomiaru temperatury podczas procesu wygrzewania próbek zastosowano trzy termopary pomiarowe: termoparę regulacyjną (TR) - mierzącą temperaturę wewnątrz pieca oraz dwie termopary mierzące temperaturę na próbce $(\mathrm{T} 1, \mathrm{~T} 2)$. Termopara $\mathrm{T} 1$ została przytwierdzona do ścianki próbki, a termopara T2 została umieszczona w nawierconym kanaliku - koniec termopary umieszczono w połowie grubości próbki. Każdorazowo wygrzewano partię
After the sample conditioning, samples of each component were divided into groups, which were then subjected to heating at $200^{\circ} \mathrm{C}, 400^{\circ} \mathrm{C}$ and $600^{\circ} \mathrm{C}$. Three thermocouples: the regulating thermocouple (RT) - measuring temperature inside the furnace - and two thermocouples measuring temperature on the sample $(\mathrm{T} 1, \mathrm{~T} 2)$ were used during sample heating. The thermocouple $\mathrm{T} 1$ was attached to the sample side, and the thermocouple T2 was placed on a bored duct, with the thermocouple's tip inserted halfway into the depth of the sample. A batch of seven test samples (three samples without fibres, 
7 próbek przewidzianych do badań (3 próbki bez dodatku włókien, 3 próbki z dodatkiem włókien oraz dodatkową 1 próbkę, na której mierzono temperaturę za pomocą termopar T1 oraz T2).

Na rycinach 4 i 5 przedstawiono widok komory pieca wraz z rozmieszczeniem w nim partii próbek przewidzianych do badań oraz próbkę, na której mierzono temperaturę.

Każdą próbkę przewidzianą do badań opisano kodem literowo-cyfrowym zgodnie przyjętym schematem (próbki z dodatkiem włókien - Z1,8F oraz próbki bez dodatku włókien - Z0F). Przyjęty kod np. 0F200/1 oznacza próbkę bez dodatku włókien, wygrzewaną w temperaturze $200^{\circ} \mathrm{C}$ o numerze próbki 1. Każdorazowo po wygrzewaniu piec wyłączano i studzono do temperatury bezpiecznej (około $100^{\circ} \mathrm{C}$ ), następnie piec otwierano i próbki schładzały się przez okres około 24 godzin do osiągnięcia temperatury pokojowej, określonej jako normalna $\left(20^{\circ} \mathrm{C}\right)$. Następnie po ostygnięciu próbki zostały poddawane badaniom wytrzymałościowym, zgodnie z założoną procedurą badawczą. three samples with fibres and one additional sample on which temperature was measured using the thermocouples $\mathrm{T} 1$ and T2) was heated each time.

Figures 4 and 5 show the furnace chamber along with the arrangement of the test samples and the sample on which the temperature was measured.

Each test sample was assigned a letter-and-number code according to a predefined pattern (samples with fibre addition - Z1.8F and samples without fibre addition - Z0F). For example, the 0F200/1 code means a sample without fibres, heated at $200^{\circ} \mathrm{C}$, whose sample number is 1 . Each time after heating, the furnace was turned off and cooled to a safe temperature (approx. $100^{\circ} \mathrm{C}$ ). Next, the furnace was opened to let the samples cool for about 24 hours to room temperature, defined as standard temperature $\left(20^{\circ} \mathrm{C}\right)$. After reaching room temperature, the samples were subjected to strength testing in line with the predefined procedure.

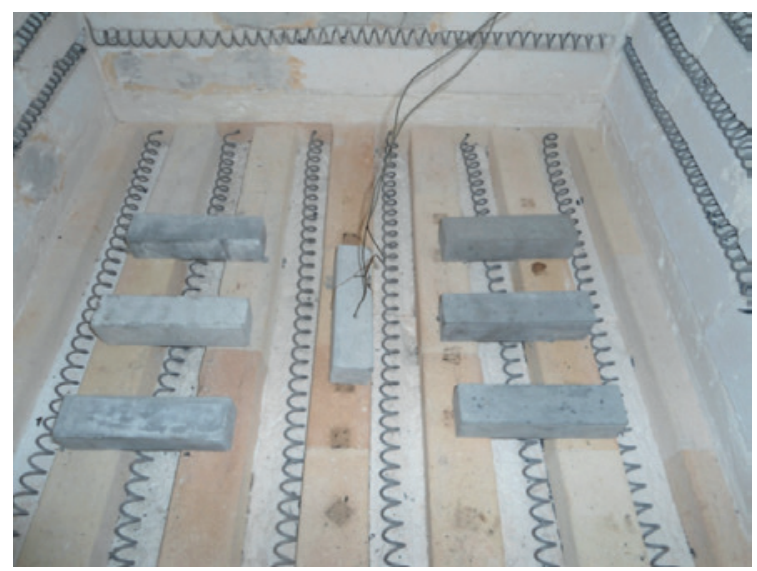

Rycina 4. Próbki prostopadłościenne w komorze pieca (gdzie: 3 próbki bez dodatku włókien; 1 próbka do pomiaru rozkładu temperatury; 3 próbki z dodatkiem włókien $\mathrm{PP}$ )

Figure 4. Rectangular-prism samples in the furnace chamber (where: three samples without fibres; one sample to measure the temperature distribution; three samples with the addition of PP fibres)

Żródło: Opracowanie własne.

Source: Own elaboration.

a)

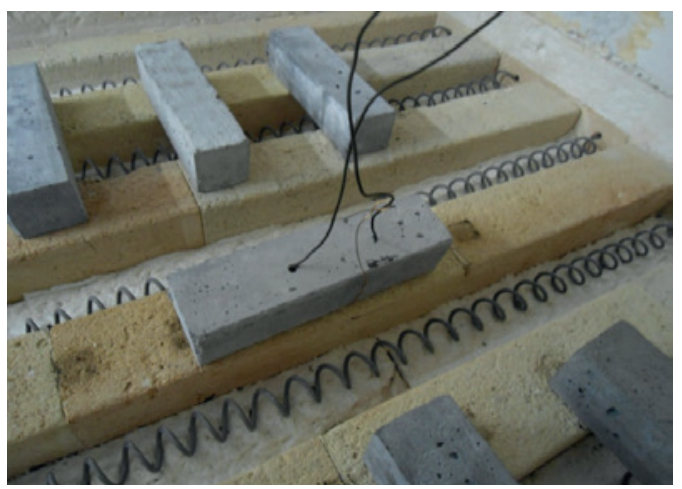

b)

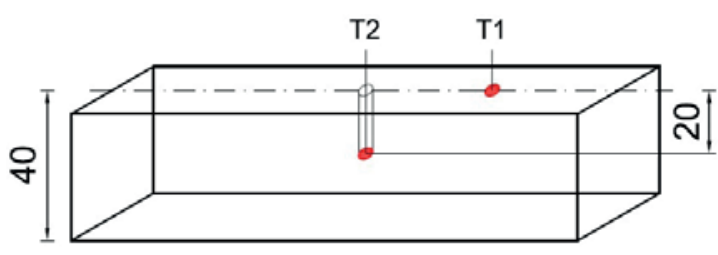

Rycina 5. Rozmieszczenie termopar pomiarowych (gdzie: a) widok próbki z zamocowanymi termoelementami; b) schemat rozmieszczenia termoelementów w próbce)

Figure 5. The arrangement of the thermocouples, where a) sample with attached thermocouples; b) diagram of the distribution of thermocouples in the sample)

Źródło: Opracowanie własne.

Source: Own elaboration. 
Próbki wygrzewano do momentu osiągnięcia przez termopary pomiarowe żądanej temperatury. Po wyrównaniu temperatury na termoparach pomiarowych utrzymywano założoną temperaturę jeszcze przez 30 minut. Następnie po ostygnięciu na wszystkich próbkach przeprowadzono testy wytrzymałości na zginanie. Na ryc. 6-8 pokazano przykładową krzywą obrazującą rzeczywisty rozkład temperatur występujących w punktach pomiarowych.
The samples were heated until the thermocouples reached the required temperature. Once the temperature was equal on thermocouples, the target temperature was maintained for further 30 minutes. Next, all the samples were cooled and subjected to flexural-strength testing. Figures $6-8$ show an example of the curve illustrating the actual distribution of temperatures at the measurement points.

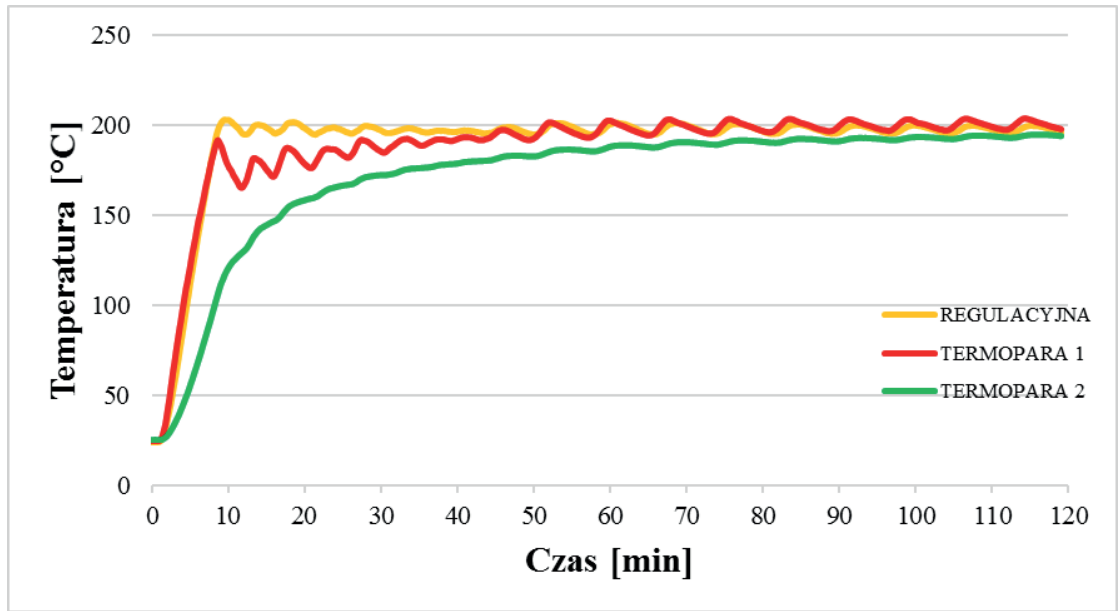

[Regulacyjna - regulating thermocouple, termopara - thermocouple, temperature - temperature, czas - time]

Rycina 6. Przebieg procesu wygrzewania w temperaturze $200^{\circ} \mathrm{C}$

Figure 6. The heating process at $200^{\circ} \mathrm{C}$

Źródło: Opracowanie własne.

Source: Own elaboration.

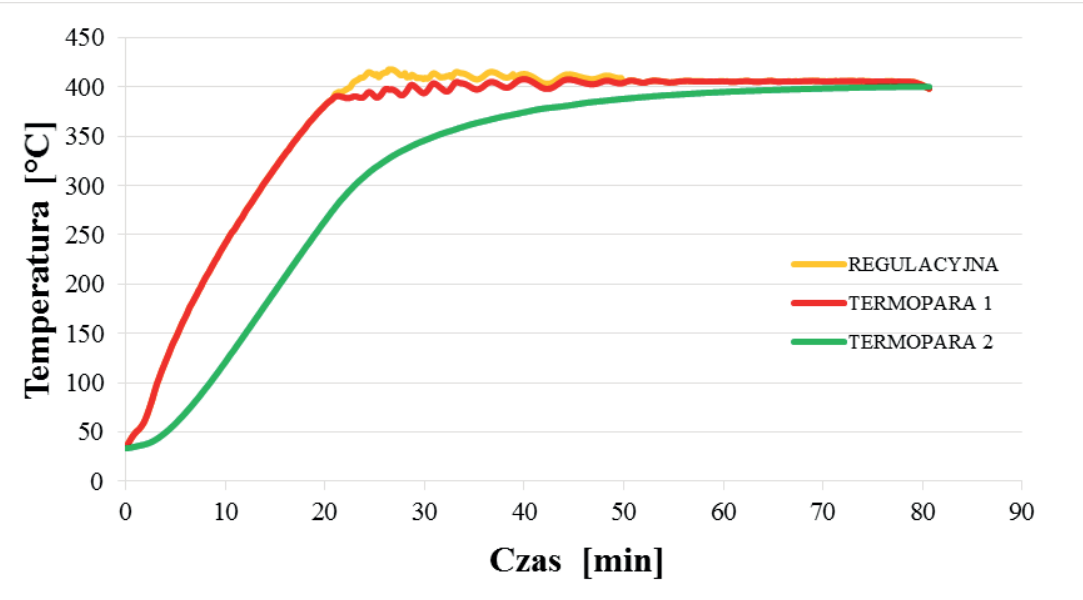

[Regulacyjna - regulating thermocouple, termopara - thermocouple, temperature - temperature, czas - time]

Rycina 7. Przebieg procesu wygrzewania w temperaturze $400^{\circ} \mathrm{C}$

Figure 7. The heating process at $400^{\circ} \mathrm{C}$

Źródło: Opracowanie własne.

Source: Own elaboration. 


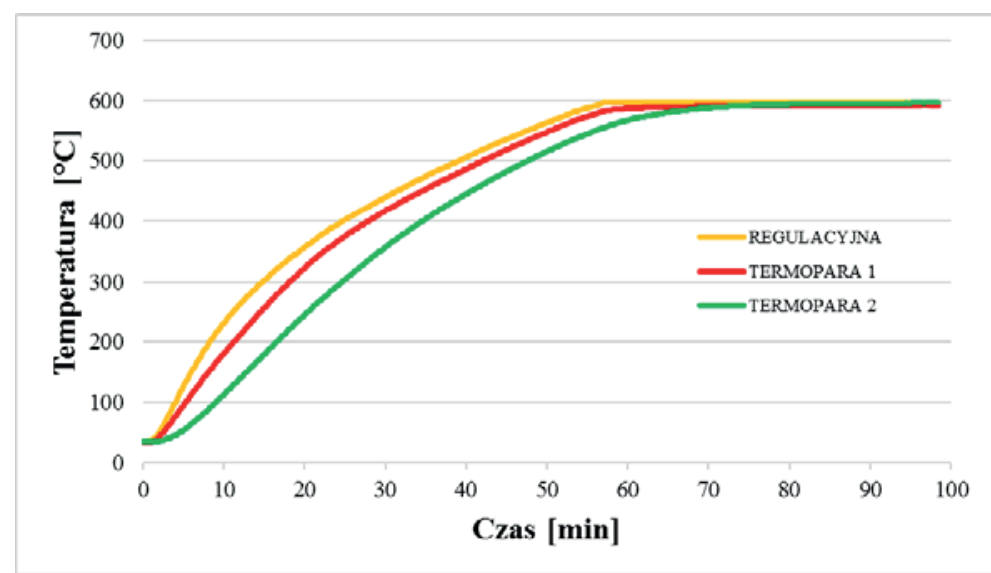

[Regulacyjna - regulating thermocouple, termopara - thermocouple, temperature - temperature, czas - time]

Rycina 8. Przebieg procesu wygrzewania w temperaturze $600^{\circ} \mathrm{C}$

Figure 8. The heating process at $600^{\circ} \mathrm{C}$

Źródło: Opracowanie własne.

Source: Own elaboration.

Stanowisko do badania wytrzymałości na zginanie

Badania wytrzymałościowe przeprowadzono w Zakładzie Inżynierii Materiałów Budowlanych na Politechnice Warszawskiej. Wytrzymałość na zginanie badano na odpowiednio przystosowanej maszynie wytrzymałościowej INSTRON 5567 o zakresie pomiarowym $0-30 \mathrm{kN}$.

\section{Flexural strength tester}

The strength tests were performed in the Institute of Construction Material Engineering, the Warsaw University of Technology. The flexural strength was tested using a properly adjusted strength tester - INSTRON 5567, with a measurement range of $0-30 \mathrm{kN}$.

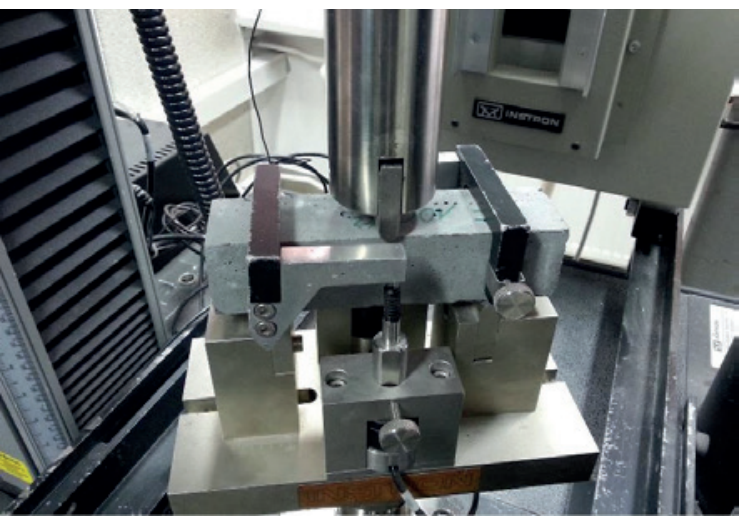

Rycina 9. Widok próbki umieszczonej w maszynie wytrzymałościowej Figure 9. The tester with a sample placed in it

Źródło: Opracowanie własne.

Source: Own elaboration.

Urządzenie podłączone było do komputera, na którym zainstalowana została aplikacja Instron Bluehill służąca do sterowania maszyną. Maszyna ta dzięki możliwości wymiany głowic i uchwytów może być wykorzystywana w szerokim zakresie badań wytrzymałościowych.

\section{Wyniki badań}

Wyniki badań przedstawiono na wykresach ilustrujących średnie wartości wytrzymałości na zginanie próbek zaprawy bez
The device was connected to a computer with the Instron Bluehill application installed to control the tester. The tester's replaceable head and handles make it suitable for a broad range of strength tests.

\section{Test results}

The test results are shown in graphs illustrating the average flexural strengths of mortar samples with and without PP fibre 
dodatku oraz z dodatkiem włókien polipropylenowych (PP) w zależności od temperatury wygrzewania. $W$ tabeli 3 zamieszczono zestawienie otrzymanych wyników badań dotyczących zmiany wytrzymałości na zginanie w procentach, gdzie wartość 100\% stanowi wytrzymałość dla próbek zaprawy bez dodatku włókien polipropylenowych otrzymaną w temperaturze $20^{\circ} \mathrm{C}$. Wyniki zmian względnej wytrzymałości na zginanie dla badanych zapraw otrzymano jako stosunek wytrzymałości na zginanie dla próbek wygrzewanych do wytrzymałości próbek niewygrzewanych $\mathrm{f}_{\mathrm{tT}} / \mathrm{f}_{\mathrm{t} 20^{\circ} \mathrm{C}}$. additions depending on heating temperatures. Table 3 lists the test results for changes in the flexural strength expressed as a percentage, where $100 \%$ is the strength of mortar samples without PP fibres obtained at $20^{\circ} \mathrm{C}$. The changes in the relative flexural strength for tested mortars were calculated as the relationship between the flexural strength for heated samples and the flexural strength for unheated samples $\left(f_{\mathrm{t} T} / \mathrm{f}_{\mathrm{t} 20^{\circ} \mathrm{C}}\right)$.

Tabela 3. Średnie wartości wytrzymałości na zginanie kompozytów z dodatkiem i bez dodatku włókien PP w zależności od temperatury wygrzewania wraz z procentowymi zmianami wytrzymałości (próbka niewygrzewana bez włókien - 100\%)

Table 3. The average values of the flexural strength of composites with and without the addition of PP fibres depending on the heating temperature, including changes in the strength expressed as a percentage (unheated fibreless sample $-100 \%$ )

\begin{tabular}{|c|c|c|c|c|c|}
\hline \multirow{2}{*}{$\begin{array}{l}\text { Próbki/ } \\
\text { Samples }\end{array}$} & \multicolumn{5}{|c|}{ Wytrzymałość na zginanie $f_{t m}$ [MPa] / Flexural strength $f_{t m}$ [MPa] } \\
\hline & & $20^{\circ} \mathrm{C}$ & $200^{\circ} \mathrm{C}$ & $400^{\circ} \mathrm{C}$ & $600^{\circ} \mathrm{C}$ \\
\hline \multirow{3}{*}{ ZOF } & $f_{\mathrm{tm}}[\mathrm{MPa}]$ & 7,7 & 7,1 & 6,3 & 5 \\
\hline & $\mathbf{f}_{\mathrm{tT}} / \mathbf{f}_{\mathrm{t} 20^{\circ} \mathrm{C}}[\%]$ & 100 & 92,21 & 81,82 & 64,94 \\
\hline & $\begin{array}{l}\text { Zmiana wytrzymałości [\%]/ } \\
\text { Change in strength [\%] }\end{array}$ & 0 & $-7,79$ & $-18,18$ & $-35,06$ \\
\hline \multirow{3}{*}{$\mathrm{Z1.8F}$} & $\mathbf{f}_{\mathrm{tm}}[\mathrm{MPa}]$ & 11 & 8,9 & 7,4 & 5,5 \\
\hline & $\mathrm{f}_{\mathrm{tT}} / \mathrm{f}_{\mathrm{t} 20^{\circ} \mathrm{C}}[\%]$ & 142,86 & 115,58 & 96,1 & 71,43 \\
\hline & $\begin{array}{l}\text { Zmiana wytrzymałości [\%]/ } \\
\text { Change in strength [\%] }\end{array}$ & 42,86 & 15,58 & $-3,9$ & $-28,57$ \\
\hline
\end{tabular}

Źródło: Opracowanie własne.

Source: Own elaboration.

Na rycinie 10 przedstawiono zestawienie średnich wartości wytrzymałościowych dla badanych zapraw cementowych z dodatkiem włókien polipropylenowych oraz bez nich, w zależności od temperatury wygrzewania.
Figure 10 lists the average strengths for the tested cement mortars with and without the addition of polypropylene fibres depending on the heating temperature.

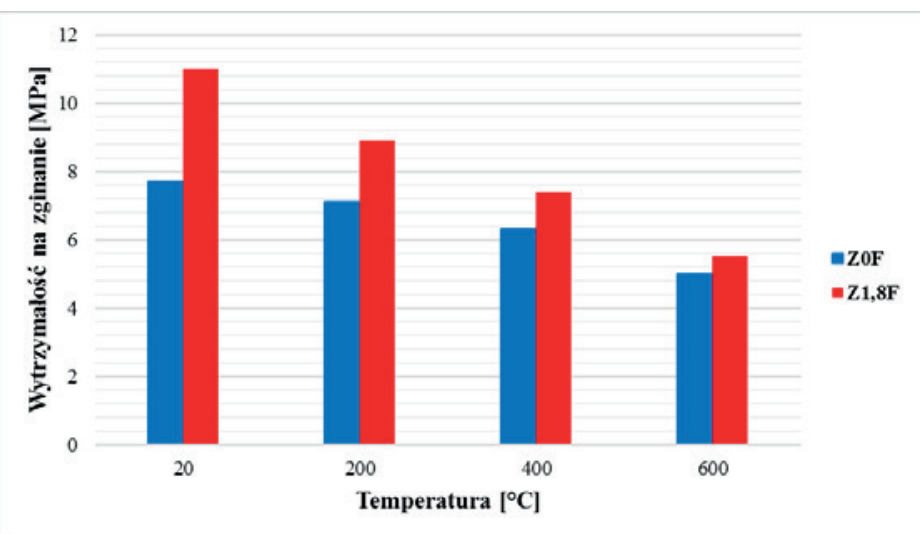

[temperatura - temperature; wytrzymałość na zginanie - flexural strength]

Rycina 10. Zestawienie średnich wartości wytrzymałości na zginanie próbek bez dodatku oraz z dodatkiem włókien polipropylenowych w różnych temperaturach

Figure 10. List of the average flexural strengths of samples with and without the addition of polypropylene fibres at different temperatures Źródło: Opracowanie własne.

Source: Own elaboration.

Po analizie otrzymanych wyników można zauważyć wyraźne umocnienie i wzrost wytrzymałości na zginanie dla próbek zaprawy z dodatkiem włókien PP w temperaturach od 20 do $400^{\circ} \mathrm{C}$. W temperaturze $600^{\circ} \mathrm{C}$ nastąpiło pogorszenie wytrzymałości zarówno dla próbek zaprawy z dodatkiem włókien, jak i bez
The analysis of the results indicates that mortar samples with PP fibres were markedly stronger, and had higher flexural strengths at 20 to $400^{\circ} \mathrm{C}$. At $600^{\circ} \mathrm{C}$, the strengths declined for mortar samples both with and without PP fibres. Notably, mortars with polypropylene fibres had higher 
włókien PP. Należy podkreślić, iż w całym zakresie temperatur od 20 do $600^{\circ} \mathrm{C}$ otrzymano wyższe wartości wytrzymałości na zginanie dla zaprawy z dodatkiem włókien polipropylenowych.

Na ryc. 11 przedstawiono zestawienie spadków wytrzymałości na zginanie w procentach, gdzie wartość $100 \%$ stanowi wytrzymałość dla próbek zaprawy bez dodatku włókien polipropylenowych nie poddanych wygrzewaniu. flexural strengths across the temperature range from 20 to $600^{\circ} \mathrm{C}$.

Figure 11 lists the decreases in the flexural strength expressed as a percentage, where $100 \%$ represents the strength of unheated mortar samples without the addition of polypropylene fibres.

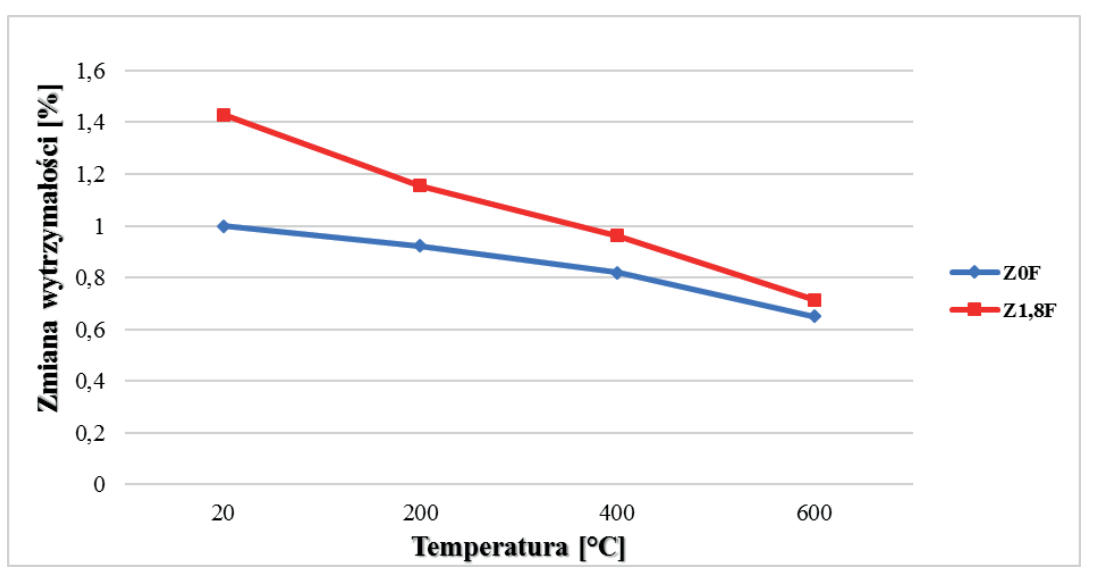

[temperature - temperature; zmiana wytrzymałości - change in strength]

Rycina 11. Zestawienie spadków wytrzymałości na zginanie próbek zaprawy bez dodatku oraz z dodatkiem włókien polipropylenowych w różnych temperaturach (próbka niewygrzewana bez włókien - 100\%)

Figure 11. List of decreases in the flexural strength for mortar samples with and without the addition of polypropylene fibres at different temperatures (unheated fibreless sample - 100\%)

Źródło: Opracowanie własne.

Source: Own elaboration.

Przeprowadzone badania wykazały, iż wytrzymałość na zginanie próbek zaprawy poddanych procesowi wygrzewania w temperaturach $200^{\circ} \mathrm{C}, 400^{\circ} \mathrm{C} \mathrm{i} 600^{\circ} \mathrm{C}$ ulega obniżeniu. Warto zauważyć, że dodatek włókien polipropylenowych (jako mikrozbrojenie próbek) sprawił, że wytrzymałość na zginanie była większa w każdym zakresie temperatur. Największa różnica zmiany wytrzymałości (tj. 43\%) próbek z dodatkiem (Z1,8F) i bez dodatku włókien (ZOF) wystąpiła w temperaturze normalnej, tj. $20^{\circ} \mathrm{C}$. Dowodzi to, że włókna PP dodane do mieszanki betonowej ograniczają powstawanie rys skurczowych oraz mikrodefektów, związanych ze skurczem wczesnym w pierwszej fazie hydratacji cementu i kształtowania się cech wytrzymałościowych. W tym celu niezbędne jest poparcie badań wytrzymałościowych analizą strukturalną (mikroskopową) pozwalającą ocenić zmiany fazowe w zaprawach i objaśnić, jakie procesy zachodzą w kompozycie.

Pozytywny wpływ dodatku włókien polipropylenowych potwierdzono w całym zakresie temperaturowym przeprowadzonych badań, które wykazały, iż zwiększają one wytrzymałość na zginanie kompozytów cementowych poddanych obróbce termicznej.

\section{Wnioski}

Po przeprowadzeniu badań wytrzymałości na zginanie zapraw cementowych z dodatkiem i bez dodatku włókien polipropylenowych, poddanych obróbce termicznej sformułowano następujące wnioski:
The tests have shown that the flexural strength of mortar samples declined when heated at $200^{\circ} \mathrm{C}, 400^{\circ} \mathrm{C}$ and $600^{\circ} \mathrm{C}$. The addition of polypropylene fibres (as sample micro-reinforcement), however, caused an increase in the flexural strength across the range of the temperatures studied. The largest change in strength (43\%) for samples with (Z1.8F) and without (ZOF) the addition of fibres was found at the normal temperature of $20^{\circ} \mathrm{C}$. This proves that the addition of PP fibres reduces contraction cracking and micro-defects associated with early contraction in the first phase of cement hydration and strength formation. Hence, it is necessary to support the strength tests with structural (microscopic) analysis, facilitating an assessment of phase changes in mortars and an explanation of the processes occurring in the composite.

The positive effect of polypropylene fibre addition was confirmed for all the temperatures studied, demonstrating that polypropylene fibres increase the flexural strength of cement composites subjected to thermal treatment.

\section{Conclusions}

The flexural strength tests of cement mortars with and without the addition of polypropylene fibres subjected to thermal treatment led to the following conclusions: 
1. W całym zakresie temperatur od $20^{\circ} \mathrm{C}$ do $600^{\circ} \mathrm{C}$ zaprawy cementowe z dodatkiem włókien polipropylenowych wykazały wyższą wytrzymałość na zginanie.

2. Największe spadki wytrzymałości na zginanie zaobserwowano w temperaturach $400^{\circ} \mathrm{C}$ oraz $600^{\circ} \mathrm{C}$. Redukcja wytrzymałości próbek z dodatkiem włókien PP w temperaturze $400^{\circ} \mathrm{C}$ względem niewygrzewanych próbek z dodatkiem włókien wyniosła $32,8 \%$, zaś w temperaturze $600^{\circ} \mathrm{C}-50 \%$. Dla próbek bez dodatku włókien spadek wytrzymałości w temperaturze $400^{\circ} \mathrm{C}$ wyniósł $18,18 \%$, a w temperaturze $600^{\circ} \mathrm{C}$ osiągnął wartość $35,06 \%$ względem niewygrzewanych próbek bez dodatku włókien.

3. Dodatek włókien polipropylenowych w ilości $1,8 \mathrm{~kg} / \mathrm{m}^{3}$ może znacząco ograniczać powstawanie rys i pęknięć w pierwszej fazie dojrzewania betonu.

4. Wykonane badania potwierdzają zasadność stosowania włókien polipropylenowych do mieszanki betonowej, ponieważ dodatek włókien poprawia wytrzymałość na zginanie zarówno w wysokich temperaturach, jak i w temperaturze normalnej (pokojowej). Pozytywny wpływ włókien polipropylenowych potwierdzają również badania przeprowadzone $w$ kraju i za granicą.

\section{Literatura/Literature}

[1] Behnood A., Ghandehari M., Comparison of compressive and splitting tensile strength of high-strength concrete with and without polypropylene fibers heated to high temperatures, "Fire Safety Journal" 2009, 44, 8, 1015-1022.

[2] Drzymała T., Jackiewicz-Rek W., Gałaj J., Šukys R.: Assessment of mechanical properties of high strenght concrete (HSC) after exposure to high temperature, "Journal of Civil Engineering and Management" 2018, 24(2), 138-144.

[3] Drzymała T., Wpływ dodatku włókien polipropylenowych do kompozytów cementowych poddanych oddziaływaniu wysokiej temperatury na ich wytrzymałość na rozciąganie, "Przemysł Chemiczny” 2017, 96(9), 1000-1003.

[4] Drzymała T., Jackiewicz-Rek W., Tomaszewski M., Kuś A., Gałaj J., Šukys R., Effects of High Temperature on the Properties of High Performance Concrete (HPC), Procedia Engineering, 2017, 172, 256-263.

[5] Drzymała T., Ogrodnik P., Zegardło B., Wpływ oddziaływania wysokiej temperatury na zmianę wytrzymałości na zginanie kompozytów cementowych z dodatkiem włókien polipropylenowych, „Technika Transportu Szynowego", 2016, 12/, 82-86.

[6] Hager I., Tracz T., Wpływ wysokiej temperatury na wybrane właściwości betonu wysokowartościowego z dodatkiem włókien polipropylenowych, „Cement, Wapno, Beton” 2009, 3-10.

[7] Jackiewicz-Rek W., Drzymała T., Kuś A., Tomaszewski M., Durability of high performance concrete (HPC) subject to fire temperature impact, "Archives of Civil Engineering", 2016,. LXII, 4, 2/2,73-93.

[8] Kuś. A., Tomaszewski M., Jackiewicz-Rek W., Drzymała T., Wytrzymałość a trwałość betonów wysokowartościowych po ekspozycji na wysoka temperaturę, "Materiały Budowlane” 2014, 10, 48-50.

[9] Tomaszewski M., Kuś A., Jackiewicz-Rek W., Drzymała T., Konsekwencje oddziaływania warunków pożaru na młody beton wysokowartościowy, "Materiały Budowlane” 2014, 10, 51-53.

[10] Ogrodnik P., Zegardło B., Halicka A., Wstępna analiza możliwości zastosowania odpadów ceramiki sanitarnej w funkcji kruszywa do
1. Across the range of the temperatures studied, from $20^{\circ} \mathrm{C}$ to $600^{\circ} \mathrm{C}$, cement mortars with polypropylene fibres exhibited higher flexural strengths.

2. The largest decreases in the flexural strength were observed at $400^{\circ} \mathrm{C}$ and $600^{\circ} \mathrm{C}$. The reduction in the strength of samples with PP fibres heated at $400^{\circ} \mathrm{C}$ and $600^{\circ} \mathrm{C}$ relative to unheated samples with $P P$ fibres was $32.8 \%$ and $50 \%$, respectively. For samples without PP fibres, the strength decreased by $18.18 \%$ at $400^{\circ} \mathrm{C}$, and by $35.06 \%$ at $600^{\circ} \mathrm{C}$ relative to unheated samples without PP fibres.

3. The addition of $1.8 \mathrm{~kg} / \mathrm{m}^{3}$ of PP fibres can, therefore, significantly reduce cracking in the first phase of concrete hardening.

4. The study has confirmed the practicability of adding PP fibres to the concrete mix, as this improves the flexural strength at both high and normal (room) temperatures. This positive effect of PP fibres has also been proven by other studies conducted in Poland and abroad.

betonów pracujących w warunkach wysokich temperatur, BiTP Vol. 25 Issue 1, 2012, pp. 49-56.

[11] Zegardło B., Ogrodnik P., Analiza destrukcyjnego wpływu nasączenia wodą na parametry wytrzymałościowe betonów poddanych warunkom pożarowym, BiTP Vol. 41 Issue 1, 2016, pp. 27-35.

[12] Han C., Hwang Y., Yang S., Gowripalan N., Performance of spalling resistance of high performance concrete with polypropylene fiber contents and lateral confinement, "Cement Concrete Research" 2005, $35,17471753$.

[13] Bednarek Z., Drzymała T., Podstawowe problemy prowadzenia działań ratowniczo-gaśniczych oraz zapewnienia bezpieczeństwa pożarowego w tunelach, "Materiały Budowlane” 2014, 10, 175-177.

[14] Drzymała T., Podstawowe problemy oraz specyfika prowadzenia działań ratowniczo-gaśniczych w tunelach drogowych, „Logistyka” 2014, 5, 364-370.

[15] Bednarek Z., Drzymała T., Migut A., Analiza bezpieczeństwa pożarowego w tunelach drogowych i kolejowych, „Budownictwo Górnicze i Tunelowe" 2014, 4, 8-12.

[16] Bednarek Z., Drzymała T., Analiza zagrożeń występujących w tunelach komunikacyjnych na skutek eksplozyjnego odpryskiwania betonu, „Obiekty Inżynierskie"r 2011, 1/(8), 31-39.

[17] Bednarek Z., Drzymała T., Zagrożenie występowania eksplozyjnego odpryskiwania betonu w czasie pożaru w tunelach komunikacyjnych, "Logistyka" 2010, 6, 173-184.

[18] Bednarek Z., Drzymała T., Wpływ temperatur występujących podczas pożaru na wytrzymałość na ściskanie fibrobetonu, "Zeszyty Naukowe SGSP" 36, 61-84.

[19] Gawin D., Witek A., Pasavento F., O ochronie betonowej obudowy tunelu przed zniszczeniem w warunkach pożarowych - wyniki projektu UPTUN, „Inżynieria i Budownictwo” 2006, 11, 622-625

[20] Gawin D., Pasavento F., Majorana C.E., Scherefler B.A., Modelowanie procesu degradacji betonu w wysokich temperaturach, „Inżynieria i Budownictwo" 2003, 4, 218-221. 
[21] Kalifa P., Chene G., Galle C., High-temperature behavior of HPC with polypropylene fibers from spalling to microstructure, "Cement Concrete Research“ 2001, 31, 1487-1499.

[22] Półka M., Drzymała T., Analiza wybranych właściwości palnych włókien polipropylenowych (PP) stosowanych jako dodatek do fibrobetonu w temperaturach pożarowych, „Przemysł Chemiczny”, 2015, 94(10), 1717-1722.

[23] Rudnik E., Drzymała T., Thermal behavior of polypropylene fiber-reinforced concrete at elevated temperatures, "Journal of Thermal Analysis and Calorimetry", 2017, 131, 2, 1005-1015.

[24] Jamroży Z., Beton i jego technologie, Wydawnictwo Naukowe PWN, Kraków 2000

[25] Drzymała T., Projekt badawczy Badanie wpływu temperatur występujących podczas pożaru na wytrzymałość fibrobetonu, BW/E-422/8/2008SGSP, Warszawa 2008.

[26] Bednarek Z., Drzymała T., Projekt badawczy, Wpływ temperatur występujących podczas pożaru na wybrane parametry wytrzymałościowe fibrobetonu, S/E-422/8/2007, I Etap, SGSP, Warszawa 2008.

MŁ. BRYG. DR INŻ. TOMASZ DRZYMAŁA - jest absolwentem studiów magisterskich Szkoły Głównej Służby Pożarniczej w Warszawie, którą ukończył w 2004 roku na Wydziale Inżynierii Bezpieczeństwa Pożarowego. W 2005 roku ukończył studia na kierunku budownictwo na Wydziale Budownictwa i Inżynierii Środowiska ATR w Bydgoszczy. W 2010 roku obronił rozprawę doktorską i otrzymał stopień doktora nauk technicznych w dyscyplinie budownictwo, nadany uchwałą Rady Wydziału Budownictwa i Architektury Politechniki Lubelskiej. Od 2011 roku zajmuje stanowisko kierownika Zakładu Podstaw Budownictwa i Materiałów Budowlanych w Katedrze Bezpieczeństwa Budowli i Rozpoznawania Zagrożeń SGSP. W ramach rozwoju naukowego uczestniczy jako prelegent w konferencjach krajowych i zagranicznych, publikuje w czasopismach fachowych. Jest autorem oraz współautorem ponad 100 artykułów i publikacji naukowych o tematyce dotyczącej ochrony przeciwpożarowej oraz budownictwa. Jego główne zainteresowanie skupia się obecnie na badaniu wpływu wysokiej temperatury na zmianę właściwości kompozytów cementowych oraz na komputerowym modelowaniu procesów gaszenia.

DR INŻ. BARTOSZ ZEGARDŁO - absolwent Wydziału Inżynierii Lądowej Politechniki Warszawskiej (kierunek: budownictwo). Do 2008 roku inżynier budownictwa pełniący funkcję kierownika budowy oraz projektanta. W 2014 roku obronił rozprawę doktorską pt. Zastosowanie odpadów ceramiki sanitarnej, jako kruszywa do betonów specjalnych.

DR INŻ. WIOLETTA JACKIEWICZ-REK - prodziekan ds. studenckich na Wydziale Inżynierii Lądowej Politechniki Warszawskiej. Od 2003 roku pracuje w Zakładzie Inżynierii Materiałów Budowlanych. Jej działalność naukowa związana jest z technologią betonów specjalnych, głównie betonów: wysokopopiołowych, samozagęszczalnych, a ostatnio - nawierzchniowych. W 2010 roku obroniła rozprawę doktorską pt. Kształtowanie mrozoodporności betonów wysokopopiołowych. Jest autorką lub współautorką około 70 publikacji z zakresu technologii betonu.

INŻ. DANIEL SOWIŃSKI - absolwent Szkoły Głównej Służby Pożarniczej w Warszawie, którą ukończył w 2017 roku na Wydziale Inżynierii Bezpieczeństwa Pożarowego.
[27] Drzymała T., Projekt badawczy, Optymalizacja ilości dodatku włókien polipropylenowych do betonu w celu przeciwdziałania eksplozyjnemu odpryskiwaniu betonu w tunelach komunikacyjnych w trakcie pożarów, S/E-422/18/14/15/16 SGSP, Warszawa 2014-2016.

[28] Brandt A.M., Zastosowanie włókien, jako uzbrojenia w elementach betonowych, Konferencja „Beton, na progu nowego milenium”, Kraków 2000, 433-444.

[29] PN-EN 1015-11:2001 Metody badań zapraw do murów Część 11: Określenie wytrzymałości na zginanie i ściskanie stwardniałej zaprawy.

[30] PN-EN 197-1:2002 Cement. Część 1: Skład, wymagania i kryteria zgodności dotyczące cementów powszechnego użytku.

[31] PN-EN 1008:2004 Woda zarobowa do betonu. Specyfikacja pobierania próbek, badania i oceny wody zarobowej do betonu".

[32] PN-EN 934-2 Domieszki do betonu, zaprawy i zaczynu. Część 2: Domieszki do betonu. Definicje, wymagania, zgodność, znakowanie i etykietowanie.

[33] Karta techniczna włókien Fibrofor High Grade 190

JUN. BRIG. TOMASZ DRZYMAŁA, PH.D., ENG. - graduated with a Master's degree from the Main School of Fire Service in Warsaw, the Faculty of Fire Safety Engineering, in 2004. Earned a construction degree from the Academy of Technology and Agricultural Sciences in Bydgoszcz, the Faculty of Construction and Environmental Engineering, in 2005. Defended his doctoral dissertation and earned the degree of Doctor of Science in the field of construction, awarded under a resolution of the Council of the Faculty of Construction and Architecture of the Lublin University of Technology, in 2010. Since 2011 he has been heading the Faculty of Construction and Construction Materials Basics at the Department of Structural Safety and Risk Identification, the Main School of Fire Service. As a researcher, he has spoken at conferences in Poland and abroad, and published in specialist journals. He has authored and co-authored more than 100 papers and research publications on fire prevention and construction. Currently, his main focus is on investigating the effect of high temperatures on changes to the properties of cement composites, and on computer-based modelling of extinguishing processes.

BARTOSZ ZEGARD $Ł O$, PH.D, ENG. - graduated in construction from the Faculty of Civil Engineering, the Warsaw University of Technology. Worked as a site manager and designer until 2008. Defended his doctoral dissertation entitled The application of ceramic sanitary ware waste as aggregate for special-purpose concrete in 2014.

WIOLETTA JACKIEWICZ-REK, PH.D, ENG. - Deputy Dean for Student Affairs at the Faculty of Civil Engineering, the Warsaw University of Technology. Has been with the Institute of Construction Material Engineering since 2003. As a researcher, she has been primarily concerned with special-purpose concrete technology, including mainly high-volume fly ash concrete, self-compacting concrete and, most recently, pavement-quality concrete. Defended her doctoral dissertation entitled Developing the freeze-thaw durability of high-volume fly ash concrete in 2010. She has authored or co-authored about 70 publications on concrete technology.

DANIEL SOWIŃSKI, ENG. - graduated from the Main School of Fire Service in Warsaw, the Faculty of Fire Safety Engineering, in 2017. 